\title{
THE PROPERDIN CONTENT OF MATERNAL AND INFANT BLOOD
}

\author{
BY \\ LOUIS L. GRIFFITHS, C. K. RAO and P. N. SWIFT \\ From the Departments of Pathology and Paediatrics, Farnborough Hospital, Kent
}

(RECEIVED FOR PUBLICATION JUNE 19, 1962)

In the course of some work on immunity at birth (Edwards, Griffiths and Swift, 1958) it became necessary to investigate the role played by properdin. We were unable to duplicate the results obtained by Pillemer, Blum, Lepow, Wurz and Todd (1956) nor were we any more successful with the modifications introduced by Isliker (1956) or Soulier, Ménaché and Larrieu (1957). Analysis of our results showed that the discrepancies could only be due to very low levels of properdin in the population, and the original technique was not sufficiently sensitive. We therefore modified the method to overcome this defect.

\section{Materials and Method}

Reagent. 1. Standard R3 prepared by Pillemer et al.'s (1956) method.

2. Fresh human serum stored at $-25^{\circ}$ C. until required.

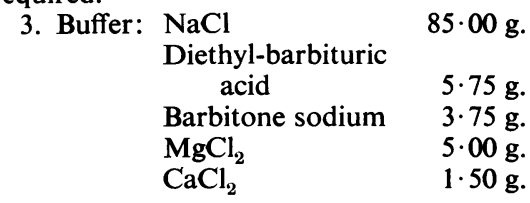

Dissolve in hot water and make up to 2 litres. Dilute with an equal amount of water for use.

4. $1 \%$ washed sheep cells sensitized with 10 units $/ \mathrm{ml}$. haemolysin.

5. Zymosan $12 \mathrm{mg} . / \mathrm{ml}$. in saline.

The test is carried out in two stages. In the first, equal quantities of serum and $\mathrm{R} 3$ are mixed. This ensures that adequate amounts of $\mathrm{C}_{1}, \mathrm{C}_{2}$ and $\mathrm{C}_{4}$ are present, and makes $C_{3}$ the limiting factor. $A$ 1/40 dilution of the mixture was titrated according to the scheme shown in Table 1 . The results are plotted, density against actual amount of serum used, and the $50 \%$ haemolytic dose calculated. This titration gives the $\mathrm{C}_{3}$ content of the serum.

In the second stage equal amounts of serum and zymosan solution are mixed and incubated at $37^{\circ} \mathrm{C}$. for one hour, inverting the tubes every 10 minutes. At this stage zymosan combines with any properdin present and the properdin-zymosan complex formed selectively removes $\mathrm{C}_{3}$ from the serum.

At the end of the incubation period the mixture is centrifuged, and to $1 \mathrm{ml}$. supernatant is added $1 \mathrm{ml}$. R3 and $3 \mathrm{ml}$. buffer. This gives a $1 / 10$ dilution of the original serum and is titrated as in Table 1 , using the $1 / 10$ dilution instead of the 1/40 dilution used in stage one. This titration gives the residual $\mathrm{C}_{3}$. The difference between the first and second titrations showed the amount of $\mathrm{C}_{3}$ removed by the properdin-zymosan complex in the proportion, according to Pillemer et al. (1956), of 1 unit properdin to 120 units $C_{3}$.

\section{Results}

The results are plotted in the Figure with the corresponding regression lines.

The mean properdin $\mathrm{C}_{3}$ levels are collected in Table 2 with the corresponding correlation coefficients and the value of Fisher's $Z$. In each case $Z$ is over nine times its standard error and is highly significant and indicates an interdependence between $\mathrm{C}_{3}$ and properdin that is extremely close. This may be due to $\mathrm{C}_{3}$ and properdin being so similar that our technique is unable to discriminate between them, or they may be present in amounts that bear

TABLE 1

\begin{tabular}{|c|c|c|c|c|c|c|c|c|c|c|c|c|}
\hline & & \multicolumn{11}{|c|}{ Tubes } \\
\hline & & 1 & 2 & 3. & 4 & 5 & 6 & 7 & 8 & 9 & 10 & 11 \\
\hline $\begin{array}{l}\text { Serum } 1 / 40 \\
\text { Buffer } \\
\text { Sensitized sheep } \\
\text { R.B.C. }\end{array}$ & $\begin{array}{l}. . \\
\therefore \\
.\end{array}$ & $\begin{array}{l}0.04 \\
0 \cdot 46 \\
0 \cdot 50\end{array}$ & $\begin{array}{l}0.08 \\
0.42 \\
0.50\end{array}$ & $\begin{array}{l}0 \cdot 12 \\
0 \cdot 38 \\
0 \cdot 50\end{array}$ & $\begin{array}{l}0 \cdot 16 \\
0 \cdot 34 \\
0 \cdot 50\end{array}$ & $\begin{array}{l}0 \cdot 20 \\
0 \cdot 30 \\
0.50\end{array}$ & $\begin{array}{l}0 \cdot 24 \\
0 \cdot 26 \\
0 \cdot 50\end{array}$ & $\begin{array}{l}0 \cdot 28 \\
0 \cdot 22 \\
0 \cdot 50\end{array}$ & $\begin{array}{l}0 \cdot 32 \\
0 \cdot 18 \\
0.50\end{array}$ & $\begin{array}{l}0 \cdot 36 \\
0 \cdot 14 \\
0 \cdot 50\end{array}$ & $\begin{array}{l}0 \cdot 40 \\
0 \cdot 10 \\
0 \cdot 50\end{array}$ & $\begin{array}{l}0.44 \\
0.06 \\
0.50\end{array}$ \\
\hline
\end{tabular}

Incubate at $37^{\circ} \mathrm{C}$. for half an hour, centrifuge and read in photometer at $550 / \mathrm{W}$. 


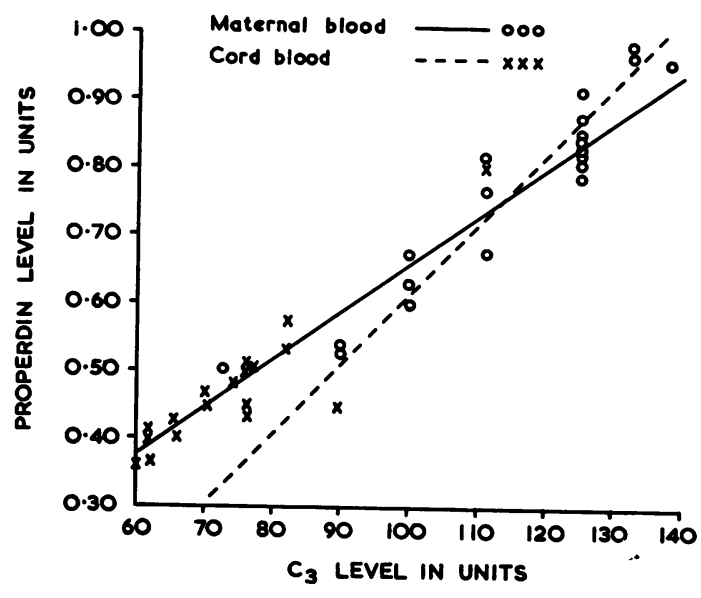

FIG.-Comparison of properdin and $\mathrm{C}_{3}$ levels.

a quantitative relation to each other. A third explanation is that the effects postulated as due to properdin are really due to $\mathrm{C}_{3}$.

The mean amount of $\mathrm{C}_{3}$ removed by the properdinzymosan complex was $78 \cdot 8 \% \pm 2 \cdot 3 \%$ for the

TABLE 2

\begin{tabular}{|c|c|c|c|c|}
\hline & & & Mothers & Infants \\
\hline $\begin{array}{l}\text { Properdin/units } \ldots \\
C_{3} / \text { units } . \\
\text { Correlation coefficient } r \\
\text { Fisher's } Z \text {. } \\
\text { Standard error of } \ddot{Z}\end{array}$ & $\begin{array}{l}\cdots \\
\cdots \\
\cdots \\
\cdots\end{array}$ & $\begin{array}{l}\ldots \\
\ldots \\
\cdots \\
\cdots\end{array}$ & $\begin{array}{r}0.76 \\
115 \\
+0.97 \\
2 \cdot 08 \\
0.23\end{array}$ & $\begin{array}{c}0.40 \\
71 \\
+0.56 \\
1.34 \\
0.23\end{array}$ \\
\hline
\end{tabular}

mothers and $78.4 \% \pm 2.6 \%$ for their infants. These are so close that it is difficult to believe that there are two independent systems present. Nelson (1958) has cast some doubt on the necessity for introducing a new immune system and our results based on different evidence are in accordance with his.

If properdin is a distinct immunological entity then the levels of Kentish mothers and their infants are far below those of their North American counterparts. Whatever the explanation we do not believe that properdin plays any part in protecting patients from infection. Our patients were completely free from any complications during the trial in spite of their properdin levels being a small fraction of those reported in similar areas in the United States.

\section{Summary}

A method is reported for the estimation of small amounts of properdin. Reasons are given for believing that its effects are really due to $C_{3}$ and that there are insufficient grounds for postulating a new immune system.

\section{REFERENCES}

Edwards, M. S., Griffiths, L. L. and Swift, P. N. (1958). Cellular immunity at birth: the mechanism and nature of the phagocytic response. Arch. Dis. Childh., 33, 512.

Isliker, H. C. (1956). The properdin system: A review. Vox Sang. (Basel), n.s. 1, 8.

Nelson, R. A. (1958). An alternative mechanism for the properdin system. J. exp. Med., 108, 515 .

Pillemer, L., Blum, L., Lepow, I. H., Wurz, L. and Todd, E. W. (1956). The properdin system and immunity III: The zymosan assay of proverdin. ibid., 103, 1 .

Soulier, J. P., Ménaché, D. and Larrieu, M. J. (1957). Dosages de Properdine-étude technique. Rev. franç. Etud. clin. biol. 2, 857. 